\title{
Trek to Everest Base Camp: (Re)composing a Sound-Trek and (Re)experiencing as Soundscape Remix
}

Guillermo de Llera Blanes

INET-md, Lisbon, Portugal ${ }^{1}$

This ethno-artistic essay proposes to contribute to debates concerning soundscape ecology, ecomusicology and the Anthropocene by investigating the human context and personal dimension of soundscape reception, perception and intervention through varying outputs. It seeks to tie in with this special issue of CfP "A Sonic Anthropocene - Sound Practices in a Changing Environment" via the suggestion of new forms of discursive involvement with the changing environment, such as artistic (re)interpretation or remix of soundscape source material, audio-visual and literary storytelling, and also textual travel logging and field notes. My goal with this essay is threefold. The first, to conduct a poietic re-signification of various soundscapes recorded in 2018 during a trek between Lukla and Mount Everest, Nepal. The second, to provide a more indepth ethno-artistic proposal via the presentation of accompanying audiovisual essays in the form of story maps (thus further demonstrating transformational processes between lived and relived experiences), and thirdly, due my own trek playing a part in the ongoing touristification of Everest, to suggest through my audio-textual-visual work - possible creative, reverential and positive potentialities in alternate methodologies for ethnographers and data-gatherers alike, particularly in

1 Instituto de Etnomusicologia - Centro de Estudos em Música e Dança (INET-md), Faculdade de Ciências Sociais e Humanas, Universidade Nova de Lisboa (FCSH-NOVA). Author's contact: yo@guillermodellera.com 
documenting the shifting Everest environment and providing a 'picture in time' of its changing land and soundscape.

Keywords: anthropocene, environmental music, soundscape composition, sound practices, soundscape ecology, ecoacoustics, ecomusicology, soundscape remix

\section{Introduction}

Soundscape Ecology as a field of environmental and academic research concerns itself primarily with inquiry and theorization concerning the collection of sounds that emanate from landscapes. It emerges as a "synthesis that leverages two important fields of study: landscape ecology and acoustic ecology" (Barrett \& Truax 2011). ${ }^{2}$ Ecoacoustics, on the other hand, develops as an interdisciplinary science that investigates sounds of natural and anthropogenic origin as conduits through which to comprehend the effects and formulations of human-natural intersections, allowing us to perceive the dynamics at play in sonic landscapes - or soundscapes - as they occur across varying scalabilities of time and space. Soundscapes, moreover, can be understood as the sonic energetic totality that emanates from a landscape via the amalgamation of three individual sonic sources: geophonies (the breeze, crashing waves, rustling leaves, etc.) , biophonies (calls, vocalizations, songs, etc.) and anthrophonies (machines hums and noises, city and transportation sounds, etc.) (Pijanowski etal 2011a, 2011b). A soundscape's sonic output can thus be viewed as resulting from the mix - or lack thereof - between natural, animal and technological inputs.

Yet the mix of geophonies, biophonies, and anthrophonies as understood by - and resulting from - human agency and intervention is both individually localized and signified. This offers an opportunity to problematize sound ecology partially through the prism of biosemiotics, by introducing the reception or perception of soundscapes, and well as human intervention in said soundscapes. Biosemiotics, as an inquiry into the creation and perception of signs and codes in the biological realm is relevant to this audio-textual-visual essay principally due to the understanding of meaning-making as a pre - or post linguistic process (Hoffmeyer 2008, Emmeche \& Kull 2011).

How individuals feel/perceive their environment is largely affected by sound, but what sounds are brought to the forefront or subdued into the sonic backdrop within the individuals' minds are products of a personalized mix of inputs, chosen by relevance to personal history, feelings, agency and preferences. Taking a phenomenological standpoint to inquiries into sound ecology and human perception allows us to consider the concept of possibility (Declerck \& Gapenne 2009). This suggests that the availability - or lack

2 The original StoryMaps have been recorded as audio-visual format for this publication. 
thereof - of actionable potentials factor into the shaping of meaning that is attributed to perceived objects or situations occurring in the environment.

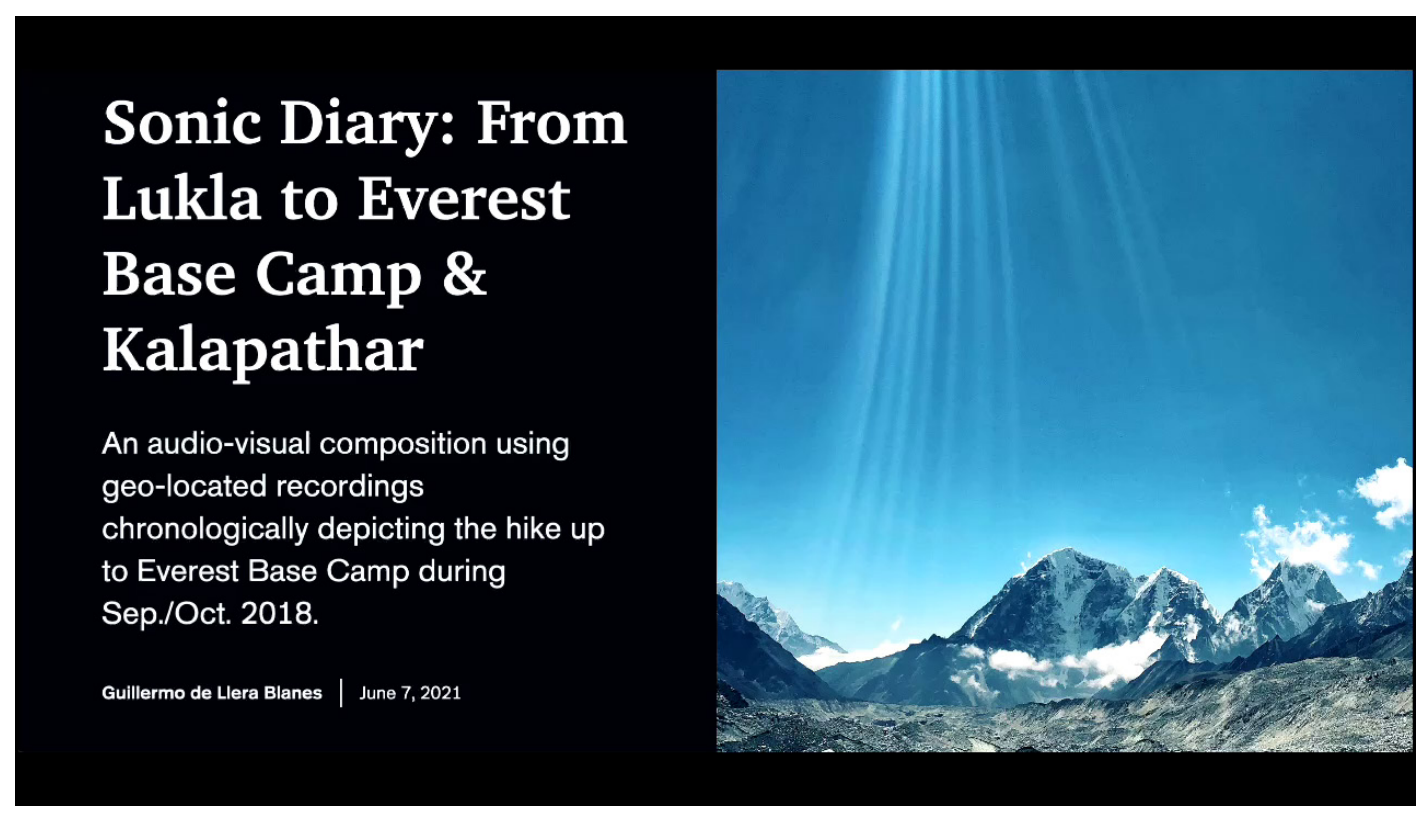

Days 1 to 3. See https://archive.org/download/trek-to-everest-base-camp/ Video\%201\%20-\%20Days\%201\%20to\%203.mp4

When Jennings and Cain affirm that "the perception of the soundscape is inherently personal and affected by what a listener, each with unique set of experiences and preferences, brings to the listening situation" (2013), they are introducing the notion of human agency as an interactive factor within soundscapes. "This framework is therefore underpinned by the proposition that a person's perception of a soundscape depends most strongly on the activity they are doing at the time, and consequently their corresponding state of listening" and operates as a contextualizing force reaching towards experiential knowing (ibid 2013) (see Dewey \& Bentley 1949). This concept is reinforced by Ingold's ideas about the apposite "deceptions of the ear" when referring to perception of the environment (2007), as well as Guillebaud's context-dependent "ways of listening" (2017).

Furthermore, Payne, Davies and Adams, when defining soundscapes state that "Soundscapes are the totality of all sounds within a location with an emphasis in the relationship between individual's or society's perception of, understanding of and interaction with the sonic environment" (2009). Thusly, although "the importance of ecoacoustic research is rapidly growing due to the increasing awareness of the intrusion of anthropogenic sounds [...] into natural and human-modified ecosystems" (Farina \& James 2016, Farina \& Gage 2017), those very same sounds can also be - or potentially become sources of creative expression and fountains of interpretative meaning. As poignantly put forth by Schafer, "Today all sounds belong to a continuous field of possibilities lying within the comprehensive dominion of music"(1977). 
Consequently, soundscapes are co-created between the soundscape as the greater whole, and the individual who experiences it, and it is with this in mind that the principal focus of this essay has been the creation of an audio-textual-visual composition via the (re)mixing of ethnographic recordings and field notes, photographs, videos, social media publications and personal experiences recorded and published by myself during a trek to Everest Base Camp in 2018.

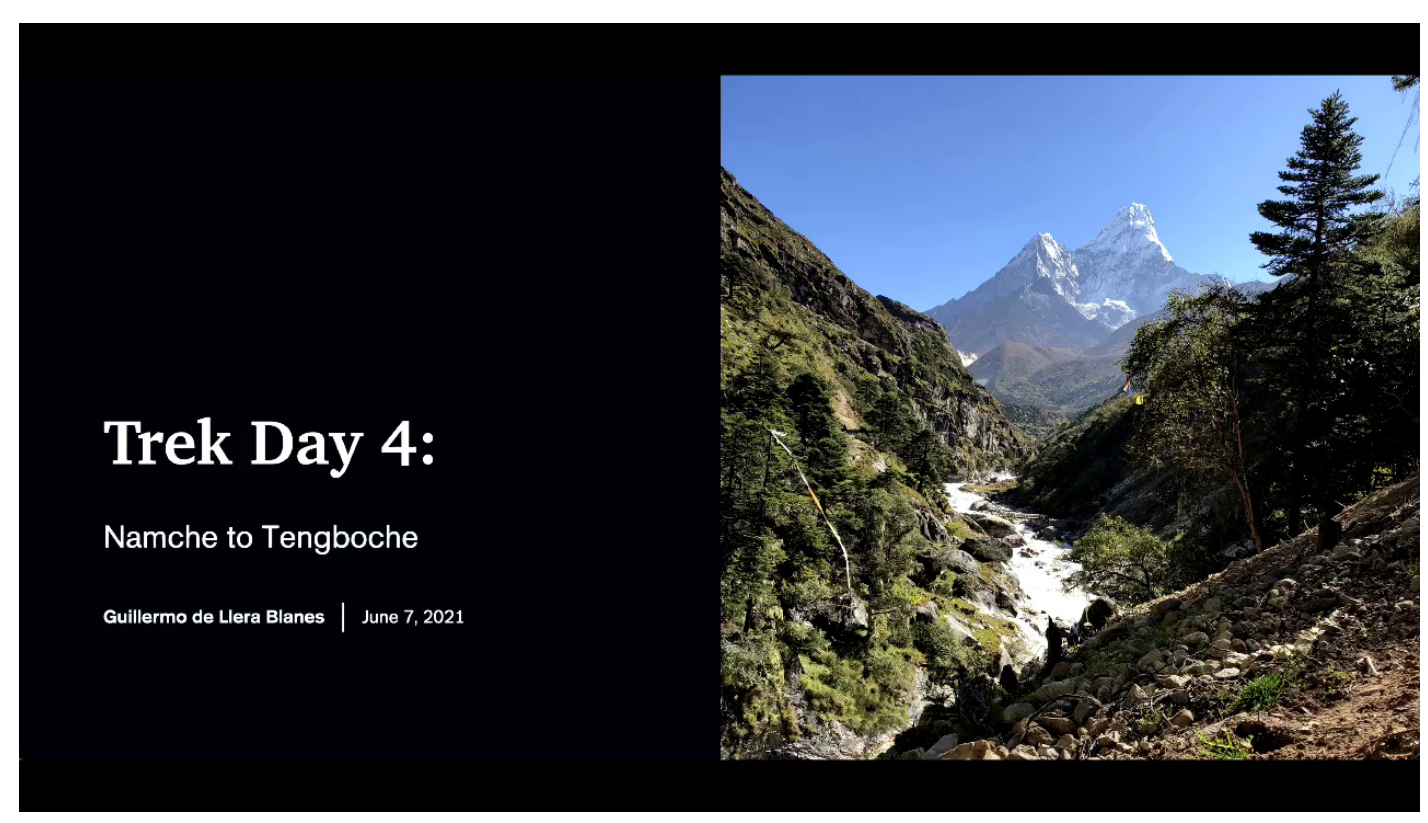

Days 4 to 6 . See https://archive.org/download/trek-to-everest-base-camp/ Video\%202\%20-\%20Days\%204\%20to\%206.mp4

This I hope to be a relevant contribution to continuing research into the fields of soundscape ecology and ecomusicology which already provide relevant findings through long-term monitoring and assessment of the environmental quality of parks and protected areas, among other important applications (Farina 2014). Previous publications have contended with the impact of human activity - particularly tourism - on Mt Everest and surrounding regions of Nepal (see Karan 1985 \& Stevens 1993, 2003), a topic of great importance considering the claim that "human agency has become the main geological force shaping the face of the earth" (Latour 2017). The geological epoch termed as the Anthopocene is a proposed age that has at its commencement the point when humans' imprint on the planet began to significantly impact nature - or the natural courses thereof -, inevitably altering the Earth's geology and ecosystems, and initiating anthropogenic climate change (See Borenstein 2014 \& Edwards 2015). The flurry and richness of debates surrounding the Anthropocene have created an Anthropo-scene, which conceptually mobilizes the Anthropocene through the following five avenues of inquiry: scientific question, intellectual zeitgeist, ideological provocation, new ontologies and science fiction (Lorimer 2016).

Considering touristification as an Anthropocentricity that precludes natural agency from geological factors is one I find disconcerting in that it obviates 
the process of 'call and response' between geophonic, biophonic, and anthrophonic agents. Therefore, this ethno-artistic essay can be taken as an attempt to emphasize the co-creative dimension between these multiple actors by way of example, and in this manner highlight possible forms of reflecting upon environmental change in the Everest through an artistic output. Every year the balance between geophonies, biophonies, and anthrophonies is altered, perhaps with greater underscoring by the latter in more recent times, yet I do believe - from personal experience - that more exposure to the facts, and more inquiry into the reasons behind the phenomenological changes to the ecology of place can lead to lesser detrimental imprints from touristification.

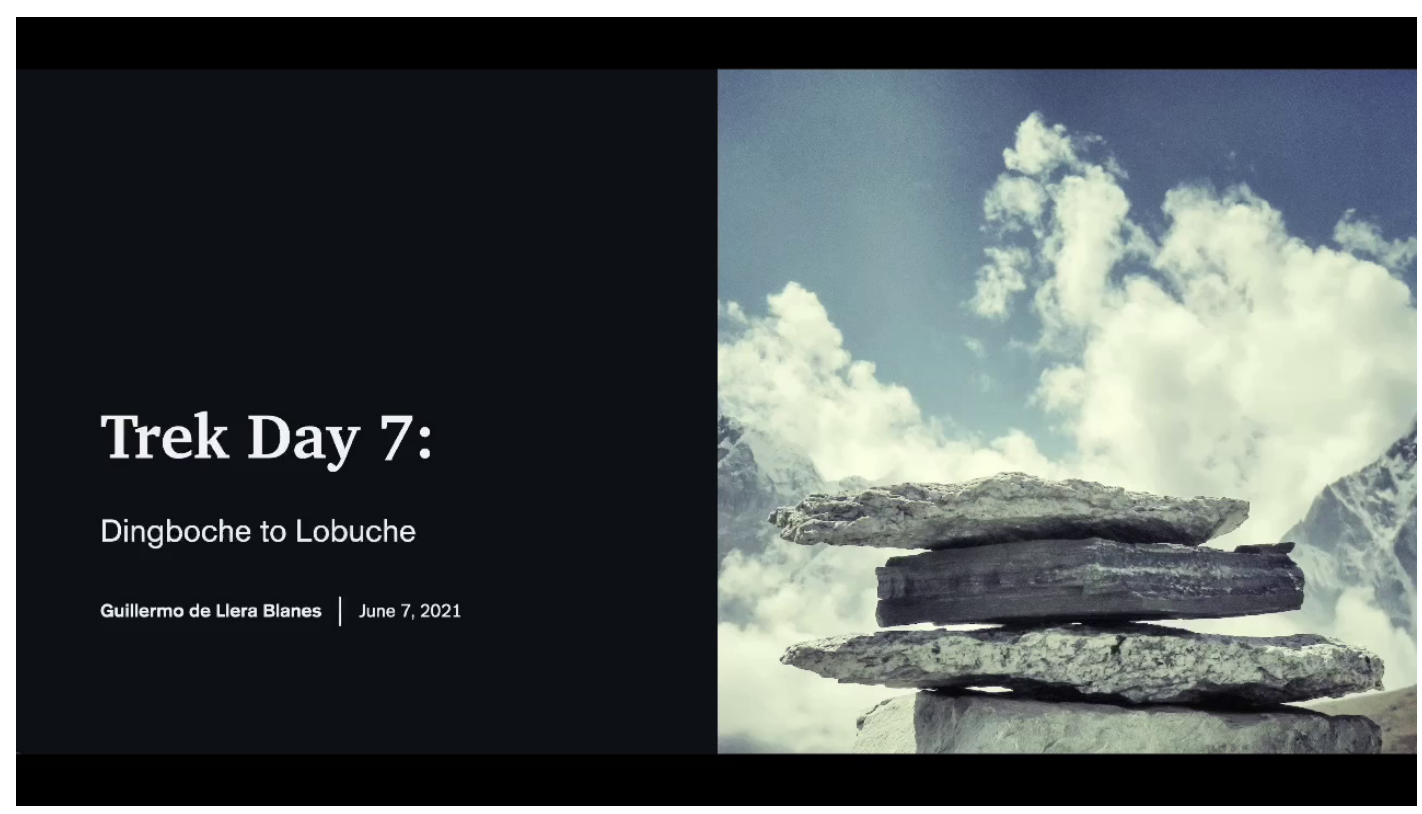

Days 7 to 9. See https://archive.org/download/trek-to-everest-base-camp/ Video\%203\%20-\%20Days\%207\%20to\%209.mp4

Yet, rather than disperse the "anthropos" in Anthropocene throughout all humankind, thus diffusing responsibility as well, one would do well to consider how historical and local networks play a part in setting the stage - so to speak - for human impact on the environment. The term Capitalocene comes to mind (Altvater et al. 2016) as a "way to ascribe [...] responsibility to whom and to where it belongs (Latour 2017:139-AAA7), in that the effects of touristification on locale should not be solely attributed to detrimental action on part of the tourist alone, but rather to a larger system, or web of capitalistic interests, that supersede individual responsibility.

Furthermore, beyond the suggestion that adopting an academic stance which employs creative interaction with the surrounding as a form of studying and performing soundscape ecology and ecomusicology is a positive way forward to these fields of study, one could also consider this interdisciplinary methodology as a tool with which to further fuel debates regarding the Anthropocene, and its function as a call to action, by highlighting how humans can engage the present moment and what they can do in the future when taking into consideration issues of environmental sustainability and 
responsibility (Crutzen \& Stoermer 2000, Waters et al. 2014, Ruddiman et al. 2015).

In this way the soundscape composition and audio-textual-visual presented in this essay aim to contribute towards more reflection about environmental change in the Everest by serving as an window to data. Rather than produce academic oratory concerning human impact on the Himalayas, it has been the goal of this essay to let the sounds and sights and travel log 'do the talking' as a metaphor of place (see Norman 2012), and through that inspire reactions from the general public ${ }^{3}$ and academia alike concerning forms and attitudes towards living soundscapes in locations suffering environmental change. It is a premise of this essay that monologue need not solely be a textual affair, and as such, that it is entirely valid to motivate action through artistic discourse, albeit in an academic realm. Another foundational pillar in my work is the proposition that in matters of import regarding places, cultures, communities and habitats facing rapid change it is vital to 'record first and ask questions later', documenting in as many formats as possible that which is changing for posterior analysis, consultation or usage for informational as well as artistic purposes.

Logging the change in Everest environment through artistic outputs or through more straightforward means such as online posting of text, audio, photo or video helps build an awareness of the current environmental situation and track certain measurable changes in the long term as well - particularly visual ones. For example, it is possible to access geolocated footage recorded by me and use it as time-stamped evidence with which to run comparisons against other data. One can also use them to observe and hear - as opposed to singly reading about - the effects of deforestation, climate change and tourist impact as an audio-visual aid to other more data-driven publications that report the environmental perils faced by the region (see for instance Stevens 1993, 2003).

Investigations into the human context and personal dimension of soundscape reception, perception and intervention through varying outputs such as the artistic (re)interpretation or remix of soundscape source material, audio-visual and literary storytelling and poetry, acoustic travel journalism, and live broadcasts among others, highlight these forms of involvement as dialogues and considerations regarding humanity's impact on the sounding Anthropocene. This is the principal form of contribution this essay has to offer, by way of example, notwithstanding the various caveats which are now evident in hindsight.

To achieve a more engaging audio-textual-visual output, it would have been helpful to spend more time between locations in the trek, capturing audio-visual material in the towns and lodges as well as in the surrounding na-

3 As the trek took place, a daily collection of items was posted to social media, to which strangers and friends alike responded daily. In a sense, posting a daily travel log served as a conduit for a shared and communal participatory experience. 
ture. With such a strategy, more complete panoramic 'pictures' of certain hotspots in the trek could have been achieved and made available online as source material for academic inquiry and artistic resource. In this way, tracking audio-visual changes would have been made possible, with long-term monitoring and measurement of soundscapes, sonic, visual and physical pollutions, as well as changes in the landscape and their detailed correlation with human activities. This methodology has been attempted since the 1980s, and today's greater technological quality and variety of recording instruments could allow for a revamped version of the these initiatives, such as the work commenced by Byers in 1987 with his publication "An Assessment of Landscape Change in the Khumbu Region of Nepal Using Repeat Photography”.

But for a more complete 'picture' of the experience itself, a more classical fieldwork methodology may have enriched my work with another layer of information. Transcriptions of talks with guides, porters, sherpas, lodge workers, service providers, healthcare professionals and also other tourists involved in the treks could have provided a glimpse of deeper dimensions at play. This would have allowed for a different sort of academic write-up that could touch upon some of the ethical issues that arise from the trek tourism industry, such as my own potential ethical breaching of rights to privacy by recording a ceremonial event for artistic recontextualization, or the recording of sounds without the explicit consent or awareness of present parties.

Moreover, various related topics could also have been explored, such as the ethics of using 'beasts of burden' to carry heavy-set humans up the steep treks. It is not uncommon to see these animals sweating profusely from the effort, their bent backs feeling relief for brief moments at the rest stops and garbage collection units, and it is another ugly truth that deserves inquiry.

The issue about tourist-related garbage has been widely debated in various publications for many decades now (see Bjønness 1980, 1983, Brower 1991, Karan \& Mather 1985, Stevens 1993, 2003, Mazolini 2010), and various projects have been implemented to address the problem (Stevens 1993:423) yet it occurs to me that a documented 'cleanup trek' could also be worthy, as a way to deal with the roughly twenty-two and a half thousand kilos of burnable waste that is produced by the seventy to one-hundred thousand yearly visitors ${ }^{4}$. Organizing a photo-logged garbage collecting trek to Everest basecamp with daily measurements and postings of images, videos and data to social media could entice further awareness of the topic and possibly foment new initiatives to address the issue.

The problematics of tourist-industry driven pollution in Upper Khumbu ${ }^{5}$ now has a 'golden' opportunity when it comes to audio-visual logging as well as measuring pollution levels and deriving statistical data from them, as the

\footnotetext{
4 Sources: www.fix.com : https://www.fix.com/assets/content/19759/human-waste-on-everest.png

5 The Mt. Everest region is locally known as Upper Khumbu (Mu \& Nepal, 2016)
} 
covid-19 pandemic has impacted the trekking industry and grinded the influx of mountaineering tourism to a halt in 2020.

Besides undertaking some of the initiatives mentioned above, my principal aim for the future is to spend more time documenting and gathering source materials for others to use as resources for artistic and academic purposes. Given the case that enough source material has been gathered and made readily available, the act of interacting with living soundscapes can be furthered by transformational processes (Bernstein 1976) of resignification. Taking Bernstein's notion of musical semantics as the proposition that meaning in music is largely metaphorical, and further diving into his suggestion that non-musical metaphorical meaning encompasses a connection of musical passages with extra-musical ideas, such as animals, emotions, or landscapes (ibid:133), my aim has been to demonstrate this process in action, by providing a metaphorical composition based on past living and present reliving of a soundscape.

Thus, based on Bernstein's ideas, and with the transformational processes of augmentation, deletion, embedding and transposition in mind, my goal to poietically re-signify pre-recordings of various soundscapes recorded on the trek between the town of Lukla and the mountain of Kalapathar facing Mount Everest was conducted. My premise subsisted in providing an audiovisual essay based on remixing the input (recorded sounds, videos, transcriptions and memory) with the output (photos, videos and text published on social media) during that period, in this way exacting a transformational process between lived and relived experiences that could hopefully serve as a functional application of a sound practice within a changing environment.

The description of the itinerary that follows is a transcription of my field notes and does not include multimedia. It concludes the academic portion of this essay, although it is not written as academic discourse, but instead in a diary fashion. Social media posts, photo galleries, videos and segments of the audio composition that help complete 'the picture' can be found in online story maps.

The online story maps are divided by day and contain audio compositions, as well as other media pertaining to that same day - when possible geolocated by latitude and longitude in interactive maps or coordinates. Descriptive text from my field notes and a copy of that day's posting on social media - in this case facebook, are also included in the story maps. A breakdown of samples that were used and were edited from geolocated audio recordings captured in the field is presented in this essay in the section that follows.

In continuing, I shall provide relevant excerpts of my field notes, while also outlining the trek itinerary. Thusly I aim to provide partial pictures of the trek as well as contextualizations of/for the location of recordings used in the audio compositions that are found on the story maps, which further detail my trek to Everest Base Camp. With this presentational methodology I hope to 
provide a multi-leveled experience of the content presented, one that grows as more 'pieces of the picture' - or tiers - are revealed.

\section{Field Notes: the Itinerary}

\section{September 25: Kathmandu to Lukla to Phakding (2610 meters)}

The flight from Kathmandu to Lukla at 2804 meters was exacting, stressful and exciting at once for those grappling with the notion of climbing to the base of world's tallest mountain and basking in its sheer magnitude. Tempers were in nervous disarray, our allotted duffle bags at overcapacity, bulked to the brim with items we would later find unnecessarily cumbersome, filling us with dread from the get-go. Kathmandu airport bustling, in a frenzy, with folks attempting to seize the break in weather. Many left behind, and we, as cash-toting foreigners equipped with guide were among the privileged few to board the small aircraft and take to the sky that morning. Soon after taking off I overheard the pilot explaining to an Australian passenger through the curtain that separated them that on that day no other flights would take off as the winds were picking up, and landing in Lukla was not an easy task. The stuff of experts for sure. There is a reason rivers of ink have been spilled describing Lukla as the world's most dangerous airport.

As we neared our destination, low air-pressure, shearing winds surrounding steep mountainous terrain, conjoined with very limited visibility turned our landing at Tenzin-Hillary Airport in Lukla into a thing of dread - and excitement. The aircraft's proximity warning alarms blared as we approached the mountain shelf and touched down upon on the 527 meter long uphill runway spooking most of us within the aircraft, except maybe for the elder Nepalese lady sitting beside me who in seeing how tightly my fists were gripping to the chair, offered me a grandmotherly smile and a piece of candy to help dispel pressure that had built up within my ears. After the 30 minute-feels-like-3 hours flight, and upon landing safely, followed a long wait in which our bags were yet again searched, and my pocket knife confiscated. We were then set loose on the town of Lukla, amidst the tourist-(un)friendly streets and waterways which carried melted waters downwards towards what - to us - felt like the rest of the distant world. After selecting our porters, we, as good westerners found a pub, played a snooker game and downed a few beers before being shushed by our guides, ears pulled and all, and pushed onto the trek towards Phakding.

That three-hour long trek took us across unimaginable landscapes, unfamiliar villages, streams, bridges, and numerous curiosities before we reached Phakding parched, and with a (more than) healthy appetite. At 2610 meters, some were already feeling oxygen deficiency, while other were missing ameni- 
ties and basic commodities. Dinner tasted fantastic, beer was expensive and tiredness felt thoroughly overwhelming. At this point we were beginning to recognize familiar faces from haphazard encounters on the trek to Phakding.

\section{September 26 \& 27: Phakding to Namche (3535 meters)}

The trek from Phakding to Namche was hard to endure but filled with awe at the surrounding nature. The ascent from 2610 to 3535 meters in altitude takes its toll physically, mentally and emotionally for any that begin to suspect altitude sickness. Those who don't begin to fear it embark on a mission to withstand crippling self-doubt about it and to help others dispel their fears and support those who are ailing. After an early 7 am breakfast we began our second day trek along Phakding village and through the local market, then crossed an iron bridge over the Dudh Koshi river. At this point it is safe to say that to most of us the 'team' was more than the group we had originally travelled with and encompassed everyone bearing the same desire to prevail, shared a sacrificial spirit and a will to bear ordeal.

After a couple of hours of what would later on - in hindsight - seem like an easy trek following the river, we finally arrived at Manjo and Jorsalle where we made a pitstop for some lunch (and latrines). The Sagarmatha National Park office Check Post is located in Jorsalle and a tourist-trekker bottleneck had formed as dozens of people scrambled to fathom the necessary steps needed to undertake in order to procure a trek permit. After entering Sagarmatha National Park it began to dawn on us that this was a necessary hardship, one which symbolized the need to renounce any anxiety or fear of pain, failure and even death. Giving in to the experience and leaving mental baggage behind at this point was a liberating feeling. It was make or break from then on. As we followed the Dudh Koshi river the trail gradually ascended until we reached the high bridge over the Bhote Koshi river. From there the trail inclined steeply all the way to Namche. Approximately 6 hours of increasing calf burn and foot hurt ended with a joyous arrival at Namche, a gorgeous village that overlooks steep crevasses and towering mountains. The first set of trial and tribulations overcome, we settled in for the night and a following day of acclimatization - one which would definitely not feel like as such when done.

After breakfast the next morning, we spent the remainder of the day hiking between Syangboche, Khungde (3840 meters) and Khumjung (3780 meters) meanwhile taking the opportunity to soak in the views of Ama Dablam, Thamserku, Kusum Kangaru, and Lhotse, avidly hoping for a peek at Mount Everest in the distance. 


\section{September 28: Namche to Tengboche (3850 meters)}

The trek from Namche to Tengboche lasted approximately 5 to 6 hours. After leaving Namche, we followed the snaking trail and within the hour we had reached Khyangjumpa at 3550 meters. From there the trail descended towards Sanasa before reaching Phunki Tenga (3150 meters) one and a half hours later. By this point, we had each made companions of silence, our usual selves left behind somewhere in what still seemed like the distant world below.

Soon after crossing the river, the trail ascended through pine, rhododendron and birch forests, and two hours later we had finally reached Tengboche, situated on a hillside from whence we could catch our first glimpse of Mount Everest, as well as an inspiring view of Mount Ama Dablam. We visited the old "Tengboche Monastery" at prayer-time, and were allowed in to sit, listen and watch in silence. I fell into a deep meditative state and experienced a waking vision that had me flying and soaring over the mountains. Possibily I was dreaming, but then - such as now - the reason mattered not, only the experience. I would dare to say that at such a depleted state, after long hours of arduous trekking up and down winding mountain paths and pristine forests, a meditative state had come over me and induced a peaceful inner silence.

\section{September 29 \& 30: Trek from Tengboche to Dingboche (4410 meters)}

As usual we began our trek early, at about 8 am. After leaving the Tengboche Monastery, we trekked down through the pine, rhododendron and birch forests and quickly (about 20 minutes later) reached Deboche, situated at 3820 meters. After another 20 minutes we crossed another bridge - this time over the Imja river, - and ascended towards Pangboche (3930 meters), where we stopped for lunch. Soon after, we continued our ascent towards the trail junction - at 4175 meters - that splits the way between Pheriche to the left and Dingboche to the right, then again we crossed the Imja river and within the hour reached Dingboche where we were to acclimatize at the elevation of 4400 meters. At this point it was safe to assume that we had all surpassed the initial risk of having altitude sickness, although nerves were still high-strung for some, particularly after sitting for a lecture at a humble local hospital at a nearby settlement. Western medical trainees had given us the rundown on the whats and whatnots with altitude sickness, yet at that point I personally felt that anything could have been thrown at us and our resolve wouldn't flinch. On our way back to the lodge at Dingboche a sudden mountain fog emerged and we lost our bearings. Luckily for us, a town dog we had befriended in Dingboche appeared -as from out of nowhere - and led the way back to the safety of the town, without which freezing to death overnight was a sure thing. 


\section{October 01: Trek from Dingboche to Lobuche (4950 meters)}

Undoubtedly, at this point, we had built up a modicum of mental and physical fortitude with which to face the last leg of our trip to Everest Base Camp and face our exhausting rise to the tip of Kalapathar. Although many were sick, and the oxygen rarefied, we endured the five hour hike to Lobuche in good spirits. The way was filled with awe inspiring imagery and bouts of perfect natural land and soundscapes, broken only by our footsteps and other westernisms (some were still donning their headphones on full tilt at that point). Later, I came to discover through conversation with various fellow trekkers, that some preferred to add a 'soundtrack' to their trek experience because it connected them to the time in their past when their dream of visiting Base camp was borne. This gave me the idea of 'sounding the trek'. To me, their sound-trek re-signification of personal history through musical association to an iconic place and experience was very interesting to say the least. The culmination of objectives or desires that had accompanied them through - in some cases - many years, and the ritual celebration of such an act by use of music as associated to the past was emblematic. As the Himalayas towered before us warping all previous conceptions regarding size, scale, height, magnitude, and overall natural power, we were all remixing what we were experiencing on a mental, physical and emotional level with our preconceptions and expectations of what the experience signified, how it should be felt, and how we were to externalize it, so why not sound-trek it, then or later.

\section{October 02: Lobuche to Gorak Shep and Everest Base Camp (5400 meters)}

It was early morning (five am) when we left for Gorak Shep and Everest Base camp. Our mood was at an all-time high during the three hour trek to Gorak Shep seeing that Everest was almost within reach, and we all felt that - at this point - nothing could take away our goal of reaching Base Camp despite the continuous helicopter fly-by's to and fro. After three hours we reached Gorak Shep which sits at 5160 meters altitude where we stopped for breakfast and a short breather before continuing on to Everest Base camp.

For some, like myself, it was time to finally commune with one of the planet's hallmarks of grandeur, beauty and power, despite the markings of human encroachment on nature, such as the plastic castaways, the wandering beasts of burden, the blaring energy generators, and most awkward of all: the noises of tourism, with the uhs, ohs and ahs echoing ubiquitously across Khumbu glacier.

Were it not for blue, and a tint of orange, the color scale would only read between white and black. The years' wear and tear had turned big rock into little rock, and to me it read as the poetry of the ages. Here, things are at play 
on a different time-scale, the soundscapes of tourism a glitch in a time-frame that cares not. There, above the world, the air is fresh, the view is fresh, feelings are fresh: as in new, and clean. Were it not product of canonical marketing and catering to the 'first' world I would not be remiss to call the experience a rite of passage. Was I not an unorthodox academic I may have ignored the spirit of the place dancing in the light. This place will see all vestiges of humankind's commodification of beauty buried under the glacier that slowly descends in millennial days, meanwhile voicing the unfathomable.

Of simple appearance yet indomitable, this is a mountain that exacts a toll, one that is transformative but that requires more than one part to leave the realm of dreams, wants and goals for future claims.

Here a metamorphosis happens, and a marriage between before you came and after you have left, something personal between you and the highest mountain on Earth. What you see, feel, hear and take back is different for each soul that sets foot on its soil, rock and ice. You can stake a claim, but it is only a claim of and for you, not a claim of and for the mountain. No one can hear you. You might as well be screaming from the moon, yet you can hear it, if you are listening at all. Only the sky towers above the peak. There is no higher. For us who stagger below it can mean many things: conquest, religion, surpassing, a mark, science, spirituality, personality, proof of value, anything. Yet the fact remains, - and it becomes quite obvious once there - we are ephemeral to the place, mere soundbites.

For this, and other reasons, I wanted to visit. To interact for a fleeting moment with that which among dust and fallen rock towers imperious over our time, beyond human ownership, property and canon, to be signified and re-signified, shared and remixed between mountain and fleeting guest.

\section{October 03: Hike / trek to Kalapathar (5545 meters)}

Kalapathar is the best vantage point from which to observe Mount Everest in closer range. We began our hike to the top in full darkness, at four am, and by keeping a quick pace I arrived a good half an hour before day break, which meant one thing: creeping coldness. The three of us who had arrived at the top first huddled together, and quickly surpassed stranger status, befriended by necessity and by sharing a common other-worldly experience. As the other tourists arrived, the top began to feel overcrowded as the sun slowly emerged to reveal Mount Everest in all its grandeur.

The wonders of technology dictate that we can record and remix our surroundings like never before. In my research, there has been a continued aim to live, experience and document - to at a later date - interpret, signify, re-interpret and re-signify, thus making a case for our power of remixing as a 
creative force, which is at the very heart of the "soundscape composition" movement.

As I assembled the story maps and worked on the audio composition, I became aware of the way raw footage selection and processing was affecting the story by subduing or omitting certain subtleties while highlighting others. A re-writing of sorts took place, one which has already affected my own memories of the experience as well as their significance to me.

Following this portion of the essay I provide a relation of audio samples that include latitude and longitude coordinates. These samples are taken from audio recordings captured on nine consecutive days. Therefore, in the resulting sound-trek, the titles of the individual audio compositions that together make the entirety of the sound-trek are titled by day and movement between places.

The prefix Movement alludes to compositional units or self-contained parts that belong in a larger unit - or composition - but that may be considered as complete compositions unto themselves (Spencer 1994). The audio recordings from which samples were taken, edited and manipulated belong to specific days in the trek. Care was taken to avoid mixing recordings from different days and thus all samples were worked into compositional movements that represented the day upon which their originating audio recording was captured.

Seeing that this is not a musical composition per se, in that I make no attempt to overlay rhythm with melody or harmony in any purposeful way, I have opted for the amalgamated term sound-trek which is wordplay between the words 'sounding' and 'trek'. Behind it is the intent to withdraw any notion of musicality by not referring to the audio compositions as musical scores but instead making homonymic reference to soundtracks as sounds - that can be musical - that accompany an audiovisual representation and enhance, or augment, the experience thereof.

It was my sincerest goal to produce work of academic and artistic value that could provide a multi-tiered perception of an experience through sound, imagery and text. The descriptions of the audio samples used, of their originating audio and of how they 'fit in' is best understood by hearing alongside reading, yet the inability to observe the entirety of this work through one medium alone means that whomever reads this text and desires to listen ${ }^{6}$ or see further is required to follow a link and continue their experience online.

6 Link to complete audio composition: https://soundcloud.com/guillermo-de-llera/theclimb-to-base-camp/s-9jsZXqyNdeh 


\section{Sound-trek (Field Recordings \& Audio Compositions)}

\section{Movement 1 - 25 $5^{\text {th }}$ of September, 2018 - Lukla to Phakding}

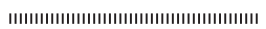

Movement 1

https: / / archive.org/download/trek-to-everest-base-camp/Movement $\% 20$

1\%20-\%2025th\%20of\%20September\%2C\%202018\%20\%E2\%80\%93\%20

Lukla\%20to\%20Phakding.mp3

แกเกเกเกเ

This track was composed as an audio description of the experience of crossing Lukla, with the sounds of mountain water flowing through it and the busy sounds of commerce and tourism that are continuous therein. The composition then describes the walk out of Lukla, passing by a bar playing music and then beginning the trek towards Phakding with the sounds of footsteps becoming more prevalent as the music slowly fades.

\section{Sound 1}

Original Audio Recording title: Lukla birds on the way to Phakding

Latitude: 27.694367

Longitude: 86.726845

Sample: Recording of the surrounding soundscape outside Lukla containing high pitched crickets, two bird calls, and two quick bursts of wind noise on the microphone that create a rhythmic pattern when looped. Wind noise has a large amount of low frequency (bass) content, often described as "wind rumble".

Sounds $2 \& 3$

Original Audio Recording title: Lukla Far Music

Latitude: 27.690602

Longitude: 86.728844

Sample: Recording of the main street in Lukla with a low percussive tone in the distance. The tone has been isolated to provide a bass note for a background beat, and the chatter of people filtered out to provide an audio background.

\section{Sound 4}

Original Audio Recording title: Lukla Prayer Bells

Latitude: 27.692215

Longitude: 86.727984

Sample:Recording of a Nepalese prayer wheel found on the outskirts of Lukla. Prayer wheels are cylindrical wheels on a spindle upon which mantras are written. 


\section{Sound 5}

Original Audio Recording title: Lukla Waterway

Latitude: 27.688086

Longitude: 86.731361

Sample: Recording of a waterway which carries melted ice water through Lukla and down the mountain. The sound of flowing water provides - together with peoples' chatter - the 'core sound' of Lukla which is a busy mid-way and departing point for tourists, traders and workers alike.

\section{Sound 6}

Original Audio Recording title: Lukla Water Outside

Latitude: 27.688632

Longitude: 86.730921

Sample: Distorted recording made accidentally in my pocket, which has been filtered to isolate the low frequencies and created a rhythmic pulse when edited and looped.

\section{Sound 7}

Original Audio Recording title: Steps and music in Lukla

Latitude: 27.690295

Longitude: 86.728942

Sample: Music excerpt recorded as I walked past a bar. It has been filtered and is edited in various places. At first the song plays uninterrupted and the steps are barely heard, but with the use of looping and filtering the footsteps are highlighted and the bass frequencies slowly subdued.

\section{Movement $2-26^{\text {th }} \& 27^{\text {th }}$ of September, 2018 - Phakding to Namche}

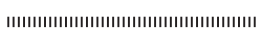

Movement 2

https: / / archive.org/download/trek-to-everest-base-camp/Movement\%20 2\%20\%E2\%80\%93\%2026th\%20\%26\%2027th\%20of\%20September\%2C\%20 2018\%20\%E2\%80\%93\%20Phakding\%20to\%20Namche.mp3

As the trek progresses, footsteps become the principal rhythm to which all other patterns relate. As we pass Upper Namche we encounter stone masons working on erecting a few more hotels, which cuts into the group conversation. The different recorded sounds are manipulated into various concurrent and overlapping rhythmic forms, then all human noise is subdued as we enter the Rhododendron forests and climb towards Namche.

Sound 1

Original Audio Recording title: Chat On The Way Up

Latitude: 27.743073

Longitude: 86.713792 
Sample: Recording of the group's conversation in Nepalese and English.

Sound 2

Original Audio Recording title: Footsteps to Namche

Latitude: 27.827504

Longitude: 86.736113

Sample: The sound of footsteps with all low frequencies filtered out.

Sound 3

Original Audio Recording title: Building A Hotel In Upper Namche

Latitude: 27.744579

Longitude: 86.712554

Sample: Recording of stonemasons picking at rock and breaking them into manageable pieces. Sampled into a loop that is compatible with the rhythm of footsteps.

\section{Sound 4}

Original Audio Recording title: Stone Workers

Latitude: 27.750528

Longitude: 86.711347

Sample: A second recording of stonemasons from a different distance.

Sound 5

Original Audio Recording title: Crickets

Latitude: 27.751591

Longitude: 86.710022

Sample: The sound of crickets with loose indiscernible human utterances and a microphone pop that is then incorporated into a composite rhythm with other samples as the composition develops.

Sound 6

Original Audio Recording title: Crickets 2

Latitude: 27.755325

Longitude: 86.710446

Sample: An isolated wind rustle and microphone pop that is sampled into a loopable rhythmic form.

\section{Movement $3-2^{\text {th }}$ of September, 2018 - Namche to Tengboche}

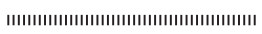

Movement 3

https://archive.org/download/trek-to-everest-base-camp/Movement\%20

3\%20\%E2\%80\%93\%2028th\%20of\%20September\%2C\%202018\%20

\%E2\%80\%93\%20Namche\%20to\%20Tengboche.mp3

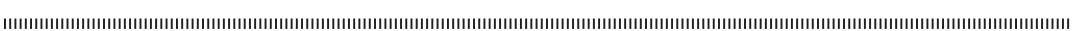


Wind, trekking, forest and sounds of crossing bridges lead into a mantra recorded at Tengboche Monastery, coupled with the rhythmic sound of monks thudding as they move, accompanied by distant bells.

\section{Sound 1}

Original Audio Recording title: Rhododendron forest Trek

Latitude: 27.828192

Longitude: 86.737214

Sample: The soundscape of walking up through forest.

\section{Sound 2}

Original Audio Recording title: The Bridge

Latitude: 27.832311

Longitude: 86.745698

Sample: A recording of the wind rustle and of the flooding river below as I crossed a bridge over a river.

\section{Sound 3}

Original Audio Recording title: Mantra at Tengboche

Latitude: 27.836124

Longitude: 86.763814

Sample: Chanting of a mantra at Tengboche Monastery, edited and then looped.

\section{Sound 4}

Original Audio Recording title: Mantra at Tengboche 2

Latitude: 27.836124

Longitude: 86.763814

Sample: Sample of a thud, used to establish a slow rhythm.

\section{Sound 5}

Original Audio Recording title: Yak Bells

Latitude: 27.853782

Longitude: 86.765008

Sample: The recording of bells on Yaks at a field near the Monastery. Filtered out and edited.

\section{Movement $4-29^{\text {th }}$ and $30^{\text {th }}$ of September, 2018 - Tengboche to Dingboche}

|

Movement 4

https://archive.org/download/trek-to-everest-base-camp/Movement\%20 4\%20\%E2\%80\%93\%2029th\%20and\%2030th\%20of\%20September\%2C\%20 $2018 \% 20 \% \mathrm{E} 2 \% 80 \% 93 \% 20$ Tengboche\%20to\%20Dingboche.mp3 
The sound of yaks, cows and bulls, donkeys and horses on the trail becomes a norm as we share the same path to and from Base Camp. As we pass the porters sometimes we are able to hear songs pouring out from their portable radios. The sounds of passing helicopters that are either taking high-paying tourists straight to the top, or are picking up trekkers that are suffering from altitude sickness becomes more frequent.

Sound 1

Original Audio Recording title: Yaks on The Trail

Latitude: 27.824819

Longitude: 86.729096

Sample: Recording of passing Yaks as they transport goods is edited and looped.

Sound 2

Original Audio Recording title: Cows On The Way Back To Namche

Latitude: 27.827504

Longitude: 86.736113

Sample: Capture of footsteps as I pass transport cows and bulls on their return down the mountain. Also edited and looped.

Sound 3

Original Audio Recording title: Song On porter's Pack

Latitude: 27.853342

Longitude: 86.777741

Sample: A looped musical excerpt recorded as I passed a porter that was resting on the side of the path. In the background the sound of a medical helicopter can be heard.

Sound 4

Original Audio Recording title: Tengboche

Latitude: 27.840967

Longitude: 86.768203

Sample: Recording of a river from a bridge above, used in its entirety.

\section{Movement 5 - $1^{\text {st }}$ of October, 2018 - Dingboche to Lobuche}

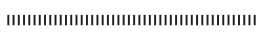

Movement 5

https://archive.org/download/trek-to-everest-base-camp/Movement\%20

5\%20\%E2\%80\%93\%201st\%20of\%20October\%2C\%202018\%20

\%E2\%80\%93\%20Dingboche\%20to\%20Lobuche.mp3

แกเกเก

Sounds from the dining hall at the lodge where we stayed. The central room was a place for meals and leisure, and due to the cold felt everywhere 
else, a gathering place for locals and trekkers. In this track we hear can instances of conversations in multiple languages and in the background a sung melody by one of the workers that sat nearby to where I was. The track then progresses into outdoor sounds of us leaving Dingboche on the path towards Lobuche.

Sound 1

Original Audio Recording title: Teahouse 1

Latitude: 27.891970

Longitude: 86.828661

Sample: Ambience recording of the common space at Dingboche lodge.

Sound 2

Original Audio Recording title: Teahouse 2

Latitude: 27.891970

Longitude: 86.828661

Sample: Another ambience recording of the common space at Dingboche lodge.

Sound 3

Original Audio Recording title: Teahouse 3

Latitude: 27.891970

Longitude: 86.828661

Sample: A third recording of the ambience at Dingboche lodge, including a sung melody heard in the background.

\section{Sound 4}

Original Audio Recording title: Dingboche Walk

Latitude: 27.905938

Longitude: 86.818254

Sample: A recording of myself trekking along the path to Lobuche.

\section{Movement 6 - $2^{\text {nd }}$ of October, 2018 - Lobuche to Everest Base Camp}

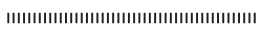

Movement 6

https: / / archive.org/download/trek-to-everest-base-camp/Movement\%20

$6 \% 20 \% \mathrm{E} 2 \% 80 \% 93 \% 202$ nd\%20of\%20October\%2C\%202018\%20

\%E2\%80\%93\%20Lobuche\%20to\%20Everest\%20Base\%20Camp.mp3

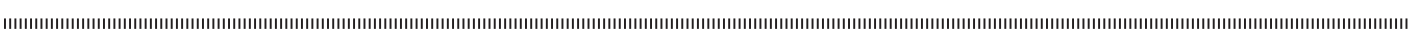

Continuing the motto from the previous movement, this audio composition features outdoor sounds, including walking, breathing, ambient sounds and crossing paths with a 'Yak train' carrying goods, with local whistles and utterances. The composition then progresses towards a more silent sound- 
scape as we near Base Camp, where little more than wind and rumbles are heard.

Sound 1

Original Audio Recording title: Lobuche Walk

Latitude: 27.939099

Longitude: 86.807271

the air.

Sample: Recording of walking and breathing heavily due to low oxygen in

\section{Sound 2}

Original Audio Recording title: Lobuche Walk 2

Latitude: 27.950050

Longitude: 86.813407

Sample: Recording of ambience including wind rumble which has been edited into a rhythm and looped.

\section{Sound 3}

Original Audio Recording title: Lobuche Yak Train

Latitude: 27.955362

Longitude: 86.815864

Sample: Recording of a group of Yaks passing through on the path, including human whistles and utterances.

Sound 4

Original Audio Recording title: Trek to Base Camp 4

Latitude: 27.982879

Longitude: 86.832392

Sample: Recording of ambience and wind on the way to Base Camp.

Sound 5

Original Audio Recording title: Trek to Base Camp 3

Latitude: 27.987996

Longitude: 86.839687

Sample: A second recording of ambience and wind on the way to Base Camp.

\section{Movement 7 - $3^{\text {rd }}$ of October, 2018 - Kalapathar}

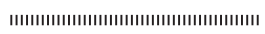

Movement 7

https:/ / archive.org/download/trek-to-everest-base-camp/Movement\%20

7\%20\%E2\%80\%93\%203rd\%20of\%200ctober\%2C\%202018\%20

\%E2\%80\%93\%20Kalapathar.mp3

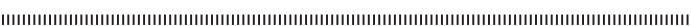


Sounds from the climb up and arrival at the tip of Kalapathar.

Sound 1

Original Audio Recording title: Kalapathar 1

Latitude: 27.992951

Longitude: 86.829377

Sample: Unedited recording of the slow walk to the climb, with ambient sounds and breathing.

Sound 2

Original Audio Recording title: Kalapathar 2

Latitude: 27.995797

Longitude: 86.828433

Sample: Unabridged recording of the arrival at the top, including conversation from people in a language I do not recognize.

\section{Bibliography}

Altvater, Elmar, Eileen C. Crist, Donna J. Haraway, Daniel Hartley, Christian Parenti, and Justin McBrien. 2016. Anthropocene or capitalocene?: Nature, history, and the crisis of capitalism. Pm Press.

Bernstein, Leonard. 1976. The unanswered question: Six talks at Harvard. Vol. 33. Harvard University Press.

Bjønness, Inger-Marie. 1980. "Ecological conflicts and economic dependency on tourist trekking in Sagarmatha (Mt. Everest) National Park, Nepal. An alternative approach to park planning." Norsk geografisk Tidsskrift Oslo 34, no. 3: 119-138.

Bjønness, Inger-Marie. 1983. "External economic dependency and changing human adjustment to marginal environment in the high Himalaya, Nepal." Mountain Research and Development: 263-272.

Brower, Barbara. 1991. "Crisis and conservation in Sagarmatha national park, Nepal." Society \& Natural Resources 4, no. 2: 151-163.

Byers, Alton. 1987. "An assessment of landscape change in the Khumbu region of Nepal using repeat photography." Mountain Research and Development: 77-81.

Borenstein, Seth. 2014. "With their mark on Earth, humans may name era, too." AP News, 2021-01-14. Available at <https://phys.org/news/2014-10-earth-humans-era. html>. Retrieved 2021-01-14.

Crutzen, Paul J., and Eugene F. Stoermer. 2000. Global change newsletter. The Anthropocene 41: 17-18. Crutzen, Paul J. "The "anthropocene". In Earth system science in the anthropocene, pp. 13-18. Springer, Berlin, Heidelberg, 2006.

Declerck, Gunnar, and Olivier Gapenne. 2009. "Actuality and possibility: On the complementarity of two registers in the bodily constitution of experience." Phenomenology and the Cognitive Sciences 8, no. 3: 285-305.

Dewey, John, and Arthur Fisher Bentley. 1960. Knowing and the known. Vol. 111. Boston: Beacon press.

Edwards, Lucy E. 2015 "What is the Anthropocene?." Eos, Earth and Space Science News 97, no. $2: 6-7$. 
Emmeche, Claus, and Kalevi Kull. 2011. Towards a semiotic biology: Life is the action of signs. World Scientific.

Farina, Almo, and Philip James. 2016. "The acoustic communities: Definition, description and ecological role." Biosystems 147: 11-20.

Farina, Almo. 2014. "Soundscape and landscape ecology." In Soundscape ecology, pp. 1-28. Springer, Dordrecht.

Farina, Almo, and Stuart H. Gage, eds. 2017. Ecoacoustics: The ecological role of sounds. John Wiley \& Sons.

Guillebaud, Christine, ed. 2017. Toward an anthropology of ambient sound. Taylor \& Francis.

Hoffmeyer, Jesper, and Donald Favareau. 2008. Biosemiotics: An examination into the signs of life and the life of signs. Vol. 2. Scranton: University of Scranton Press.

Ingold, Tim. 2007. 2007 . "Against soundscape", in Carlyle, Angus. Autumn leaves: sound and the environment in artistic practice. CRiSAP/Double Entendre.

Jennings, Paul, and Rebecca Cain. 2013. "A framework for improving urban soundscapes." Applied Acoustics 74, no. 2: 293-299.

Karan, P. P., and Cotton Mather. 1985. "Tourism and environment in the Mount Everest region." Geographical Review 75, no. 1: 93-95.

Latour, Bruno. 2017. "Anthropology at the time of the Anthropocene: a personal view of what is to be studied." In The anthropology of sustainability, pp. 35-49. Palgrave Macmillan, New York.

Lorimer, Jamie. 2017. "The Anthropo-scene: A guide for the perplexed." Social Studies of Science 47, no. 1: 117-142.

Mazzolini, Elizabeth. 2010. "Food, waste, and judgment on Mount Everest." Cultural Critique 76: 1-27.

$\mathrm{Mu}$, Yang, and Sanjay Nepal. 2016. "High mountain adventure tourism: Trekkers' perceptions of risk and death in Mt. Everest Region, Nepal." Asia Pacific Journal of Tourism Research 21, no. 5: 500-511.

Payne, Sarah R., William J. Davies, and Mags D. Adams. 2009. "Research into the practical and policy applications of soundscape concepts and techniques in urban areas".

Pijanowski, Bryan C., Luis J. Villanueva-Rivera, Sarah L. Dumyahn, Almo Farina, Bernie L. Krause, Brian M. Napoletano, Stuart H. Gage, and Nadia Pieretti. 2011. "Soundscape ecology: the science of sound in the landscape." BioScience 61, no. 3: 203-216.

Pijanowski, Bryan C., Almo Farina, Stuart H. Gage, Sarah L. Dumyahn, and Bernie L. Krause. 2011. "What is soundscape ecology? An introduction and overview of an emerging new science." Landscape ecology 26, no. 9: 1213-1232.

Rudimann, Wiliam F., Erle C. Ellis Jed O. Kaplan, and Dorian Q. Fuller. 2015. "Defining The Epoch We Live In: Is A Formally Designated 'Anthropocene' a Good Idea?.” Science 348, no. 6230: 38.

Schafer, R. Murray. 1977. "Introduction". The Soundscape: Our Sonic Environment and the Tuning of the World, 2-12, 205- 225. Rochester: Destiny Books, 1994.

Spencer, Peter, and Peter M. Temko. 1994. A practical approach to the study of form in music. Waveland Press.

Stevens, Stan. 2003. "Tourism and deforestation in the MtEverest region of Nepal." Geographical Journal 169, no. 3: 255-277.

Stevens, Stanley F. 1993. "Tourism, change, and continuity in the Mount Everest region, Nepal." Geographical Review: 410-427.

Truax, Barry, and Gary W. Barrett. 2011. "Soundscape in a context of acoustic and landscape ecology.” Landscape Ecology 26, no. 9: 1201-1207. 
Norman, Katharine. 2012. "Listening together, making place." Organised Sound 17, no. 3: 257.

Waters, Colin N., Jan A. Zalasiewicz, Mark Williams, Michael A. Ellis, and Andrea M. Snelling. 2014. "A stratigraphical basis for the Anthropocene?." Geological Society, London, Special Publications 395, no. 1: 1-21.

Date received: 2020-08-14

Date accepted: 2021-03-19 